Rami Mähkä

\section{"JOKAISEN ON VALITTAVA PUOLENSA" \\ Suomen sisällissota 2000-luvun kotimaisessa elokuvassa}

Artikkelissa tarkastellaan viittä 2000-luvulla tehtyä Suomen sisällissotaan sijoittuvaa elokuvaa historiallisina elokuvina. Analyysin keskiössä on kysymys, millaista historiallista tietoa elokuvat sisällissodasta antavat ja miten tämä korreloi sisällissodan muistelun ja tutkimuksen kanssa. Elokuville on tyypillistä sijoittuminen sodan loppuvaiheeseen ja sodan hävinneen punaisen osapuolen kokemiin julmuuksiin. Vastaavasti sodan syyt ja erityisesti punaisten johto on suljettu sodan representaatioiden ulkopuolelle.

Vuonna 2007 ensi-iltansa saaneen elokuvan Raja 1918 (ohjannut Lauri Törhönen) mainoslause niin elokuvateatteri- kuin televisiomainonnassakin oli "Jokaisen on valittava puolensa". Suomen sisällissodan loppuun ja sen jälkeisiin kuukausiin sijoittuva elokuva kertoo valkoisten puolella taistelevasta aatelisupseerista, jonka tehtäväksi annetaan itsenäistyneen Suomen ja Venäjän välisen rajavartioaseman perustaminen. Bolsevikkihallintoa pakoon Suomeen pyrkivien venäläisten ohella raja-alueella liikkuvat Venäjälle pyrkivät, valkoisten rangaistusta pakenevat punakaartilaiset. Tavallisten ihmisten on toistuvasti valittava, auttavatko he virallista Suomea edustavia valkoisia saamaan punaisia kiinni vai - henkensä uhalla - punaisia pakenemaan Neuvosto-Venäjälle.

Vaikka elokuvan mainosslogan viittaa itse elokuvaan, voi väittää, että se samalla vetoaa suomalaisyleisöjen - elokuvan keskeisin kohderyhmä sen kansainvälisestä jakelusta huolimatta - sympatioihin jompaakumpaa sisällissodan osapuolta kohtaan. ${ }^{1}$ Tätä korostaa aktiivimuoto "on" - toinen vaihtoehto olisi ollut menneisyyteen viittaava imperfekti "oli". Elokuva ikään kuin kutsuu katsojan identifioitumaan punaisiin tai valkoisiin ja näin ylittämään elokuvan tekoajan ja historian välisen rajan. Elokuvan tarinan henkilöhahmot edustavat sisällissodan osapuolia vain tiettyyn pisteeseen asti, mutta mainoslause vetoaa myös suomalaisten tietoisuuteen sisällissodan muistosta edelleen yhteiskunnassamme vaikuttavana historiallisena tragediana.

Journalistiikantutkija Esko Salminen (2007, 5-6, passim.) puhuukin sisällissodasta "päättymättömänä sotana" ja kirjoittaa, että "arkaluontoinen sisällissota herättää yhä vahvoja tunteita, sodan arvet ovat pitkäikäisiä". Ulla-Maija
Rami Mähkä, FT,

kulttuurihistoria, Turun yliopisto

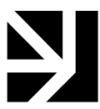

VERTAISARVIOITU

KOLLEGIALT GRANSKAD

PEER-REVIEWED
1 Toisaalta on mielenkiintoista pohtia, millaisen käsityksen elokuvat antavat Suomen historiaa tuntemattomalle ulkomaiselle katsojalle. Raja 1918:n kansainvälinen nimi on "The Border", joka ei viittaa mitenkään Suomen sisällissotaan, kuten ei myöskään tee Käskyn kansainvälinen nimi "Tears of April". 
Peltonen $(2003,198)$ kirjoitti puolestaan jo muutamaa vuotta aiemmin, että "sisällissodan jälkihoito on Suomessa vielä 2000-luvun alussa kesken". Tämän artikkelin lähtökohta on, että sisällissota on edelleen ajallisesta etäisyydestään huolimatta monien suomalaisten sekä identiteettiä että yhteiskunnallista ja poliittista ajattelua jäsentävä historiallinen tapahtuma. ${ }^{2}$ Vaikuttaa siltä, että sisällissodan muistelu ja käsittely ovat edelleen heiluriliikettä sen viihteellisen ja poliittisen hyödyntämisen sekä kansallisten traumojen parannusyritysten välillä. (Ks. myös Salminen 2007, 5, passim.)

Käytän artikkelissa Suomen vuoden sodasta nimeä "sisällissota", mikä on tutkimuksessa vakiintunut termi (vrt. "kansalaissota", "vapaussota", "punakapina"). Kuten historioitsija Pertti Haapala (2009, 10, passim.) toteaa, "sisällissota" on termeistä siinä mielessä neutraalein, että se sisältää keskeiset faktat: huolimatta ulkovaltojen vaikutuksesta, sodan aloittivat, kävivät ja ratkaisivat suomalaiset Suomessa, ja he myös elivät keskenään itsenäisessä Suomessa sodan jälkeen. Termiä käytetään myös 2000-luvun elokuvien yhteydessä poikkeuksetta. Suomalaisten voi olettaa tietävän jo kouluopetuksen ansiosta sisällissodasta edes perusasiat, mikä on otettava huomioon elokuvien ja niiden historiakuvauksen analyysissa. Vaikka tämä vaikuttaa itsestään selvyydeltä, seikka on tiedostettava, kun elokuvien sisällissotakuvausta tarkastelee sodan historiantutkimuksen antamaa kuvaa vasten.

Artikkelin pääkysymys on, miten 2000-luvun suomalaiset sisällissotaelokuvat kuvaavat Suomen vuoden 1918 sisällissodan historiallisena tapahtumana. Millaisia sisällissotaan sijoittuvia tarinoita ne kertovat? Millä tavoin elokuvat osoittavat historiallisuutensa, eli millaisin eksplisiittisin historiallisin koordinaatein ne sijoittavat kertomansa tarinat historiaan? Ketkä edustavat elokuvissa punaisia ja valkoisia? Mitä asioita sisällissodasta nostetaan esiin, mitä taas ei käsitellä?

Sisällissodasta on tehty elokuvia pitkin 1900-lukua, mutta tarkastelen sitä, miten sisällissodan representaatiot 2000-luvun elokuvissa on ymmärrettävissä suhteessa sisällissodan mieltämiseen ja käsittelyyn suomalaisessa yhteiskunnassa. Koska artikkelin näkökulma on historiallinen, kontekstualisoin elokuvien käsittelemiä aiheita ja teemoja sisällissodasta tehtyyn historiantutkimukseen. Artikkelin lähtökohta on, että elokuvat yhtäältä heijastavat suomalaisessa yhteiskunnassa vaikuttavia tietoja ja käsityksiä sisällissodasta, mutta samalla ne vaikuttavat suomalaisten käsityksiin siitä.

Artikkelin lähdeaineisto koostuu 2000-luvulla teatterilevitykseen tehdyistä, ${ }^{3}$ Suomen sisällissotaan ja usein sen traagiseen jälkinäytökseen sijoittuvista elokuvista. Käsiteltäviä elokuvia on viisi: Raja 1918 (Törhönen, 2007), Käsky (Aku Louhimies, 2008), Täällä Pohjantähden alla (Timo Koivusalo, 2009), Täällä Pohjantähden alla II (Koivusalo, 2010) sekä Taistelu Näsilinnasta 1918 (Claes Olsson, 2012). ${ }^{4}$ Pohjantähti-elokuvat sijoittuvat paljon pidemmälle aikavälille kuin vain sisällissotaan. Sisällissodan osuus ja merkitys on kuitenkin keskeisin osa Pohjantähti-elokuvia, joiden tarina on vaikuttanut suomalaisten käsityksiin sisällissodasta vuosikymmenet, ja sisällissodan tulkinta on niissä historiallisesti kaikkein kattavinta käsitellyistä elokuvista.

Elokuvien taustoihin viitataan jatkossa, mutta yhteenvetona voi jo tässä yhteydessä todeta, että Raja 1918 ja Taistelu Näsilinnasta 1918 perustuvat alkuperäiskäsikirjoituksiin, Käsky Leena Landerin samannimiseen romaaniin (2003), josta tehtiin elokuvaa ennen sovitus Kansallisteatteriin 2006. Elokuvaversiota varten tehtiin oma käsikirjoitus. Täällä Pohjantähden alla jatko-osineen perustuu Väinö Linnan romaanitrilogiaan (1959-1962), josta on tehty aiemmin kaksi elokuvaa: Täällä Pohjantähden alla (Edvin Laine, 1968) ja Akseli ja Elina
2 Tästä on ollut merkkejä aivan viime aikoina, muun muassa kevään 2017 niin sanotun "juhlarahakohun" yhteydessä, tai vuodenvaihteessa 2018 voimakkaina reaktioina Suomen hallituksen työvoimapoliittisiin päätöksiin eli työttömien aktiivimalliin ja sote-uudistukseen. Ks. tämän Lähikuvan pääkirjoitus

3 Vuonna 2000 ilmestyi Olli Soinion ohjaama tv-elokuva Pako punaisten päämajasta. Ensiesitys YLE1 Kotikatsomo 9.10.2000.

4 Sisällissota on osa tarinaa 2000-luvulla joissain muissakin suomalaiselokuvissa, kuten Colorado Avenue (Olsson 2007) ja Missä kuljimme kerran (Peter Lindholm 2011), mutta niitä en käsittele artikkelissa. Heikki Kujanpään sisällissotaan sijoittuvan Suomen hauskin mies -elokuvan ensiilta oli puolestaan 16.3.2018, liian myöhään systemaattisen käsittelyn kannalta tässä artikkelissa. Elokuvaa käsitellään tämän Lähikuvan numeron pääkirjoituksessa. 
(Laine, 1970). Lähestyn kuitenkin Koivusalon Pohjantähti-elokuvien sisällissotakuvausta uusina, aiempien versioiden (kirjallisuus, teatteri, aiemmat elokuvat) tuntemusta edellyttämättöminä tulkintoina sisällissodasta, sillä oletan, että sellaisiksi ne on tehty: kenen tahansa on ymmärrettävä elokuvat ilman aiempien Pohjantähti-teosten tuntemusta. ${ }^{5}$

Metodologinen lähestymistapani on seuraava: analysoin elokuvatekstejä näkökulmastani johtuen usein pieninekin yksityiskohtineen. Kyse ei ole elokuvatekstien analyysista taiteellisina teksteinä, vaan niiden lähiluvusta suhteessa siihen, miten ne ovat vuorovaikutuksessa Suomen sisällissotaan historiallisena ja julkisesti muistettuna tapahtumana. Esittelen elokuvien tarinan ja perusasetelmat, mutta näen elokuvat toisistaan riippumattomina teoksina, joille on periaatteessa yhteistä vain eksplisiittinen sijoittuminen Suomen sisällissotaan: artikkelissa on siis kyse ennen kaikkea tiettyyn historialliseen tapahtumaan liittyvien aiheiden esittämisen analyysista ja historiallisesta kontekstualisoinnista eli historiallisen elokuvan tutkimuksesta.

\section{Sisällissotaelokuvat historiallisina elokuvina}

Ymmärrän sisällissotaelokuvat kertomuksina historiasta ja sellaisina osana suomalaista historiakulttuuria. Historiakulttuuria ovat kaikki tavat, joilla yhteisöt muistavat ja representoivat menneisyyttä kouluopetuksesta virallisiin muistopäiviin, museonäyttelyihin, historiikkeihin, poliitikkojen historiaan viittaamiseen sekä akateemiseen historiantutkimukseen. Viimeksi mainittu on historiakulttuurin periaatteessa arvovaltaisin, mutta ei yleensä vaikutusvaltaisin muoto. (Salmi 2001, 134-135; Mähkä 2016, 10.) Elokuva on ollut ja on suosittuna taidemuotona edelleen erittäin vaikutusvaltainen historiakulttuurin muoto, kun ajatellaan yleisiä mielikuvia historiasta. Siksi on tärkeä selvittää, millaista kuvaa 2000-luvun teatterielokuva sisällissodasta esittää.

Historiallinen elokuva on helppo määrittää elokuvaksi, joka ekspliittisesti sijoittuu menneisyyteen. Sen sijaan historiallisen elokuvan tapa käsitellä jotain tiettyä historiallista tapahtumaa tai periodia on paljon monimutkaisempi kysymys. Kuten Hannu Salmi (1993, 218-219) painottaa, historiallista elokuvaa tutkitaan sen tuottaneen aikakauden ilmentymänä, ei todistusaineistona siitä, millainen sen kuvaama menneisyys oli. Yhtäältä kyse on kiinnostuksesta historian tulkintoihin, toisaalta niihin ajankohtaisiin kysymyksiin ja arvoihin, jotka vaikuttavat elokuvan tuotantoaikana. Tässä mielessä historiallisen ja nykypäivään sijoittuvan elokuvan raja muuttuu monimutkaisemmaksi, mutta oleellista on, että historiallinen elokuva sijoittuu eksplisiittisesti menneisyyteen. Historiallista elokuvaa voi siis samalla pitää historiallisen ajattelun tai pohdiskelun muotona, kuten Robert Rosenstone (2013) tekee (ks. Mähkä 2016, 4-5).

Rosenstonen mukaan valtavirran historiallinen elokuva ei avaa ikkunaa menneisyyteen, vaan näyttävän visualisoinnin tukemana esittää "etäisen approksimaation" siitä, mitä kuvatussa menneisyydessä tapahtui ja mitä sanottiin. Rosenstonelle tämä on tietyssä mielessä paradoksaalista: kaikkein "sanatarkin" - siis audiovisuaalisuutensa vuoksi kokonaisvaltaisimman esityspotentiaalin omaava - media ei tarjoakaan "kirjaimellisinta" representaatiota menneisyydestä. Tämä johtuu valtavirran historiallisen elokuvan kerrontakonventioista: lajityypissä historia on pääsääntöisesti lineaarinen, sulkeistettu tarina, jolla on alku ja loppu. Tämä johtuu pitkälti siitä, että lajityypissä historia on tarina yksilöistä ja heidän ongelmistaan, ja heidän
5 Vastaava, tuoreempi tapaus on Louhimiehen Tuntemattoman sotilaan uudelleenfilmatisointi (2017). 
ongelmiensa selvittäminen korvaa ne historialliset ongelmat, joista elokuvassa päällepäin näyttäisi olevan kysymys. (Rosenstone 2000, 29-31, 34.)

Elokuvan kertoman tarinan ja historiantulkintojen välinen suhde on kuitenkin kaksisuuntainen. Tom Conley $(2011,146)$ kirjoittaa, että historiallista elokuvaa määrittävä ominaisuus on "keston kompressio", eli historia pakataan mahtipontisissa lavasteissa esitetyn "perheromanssin" tarinaan. Leger Grindon (1994, 15-16) kuitenkin painottaa, että näyttävä historiallinen epookki ei ole pelkkä passiivinen lavaste elokuvan tarinalle vaan aktiivisen historiallisen merkityksellistämisen väline. Huomattavin yhdistävä piirre on, että Pohjantähteä lukuun ottamatta elokuvissa on ilmeinen haluttomuus olla pohtimatta sisällissodan syitä, mikä reflektoi vahvasti sisällissodan muistelua ylipäätään, kuten alla esitän.

\section{Sisällissota ja Suomen sisällissota}

Raja 1918:n ensimmäinen kohtaus on taistelu, jossa valkoinen osasto hyökkää punaisten asemiin. Tilannetta seuraa kiikareillaan elokuvan toinen keskushahmo, valkoupseeri, kapteeni von Munck (Martin Bahne). Seuraa sekava ja brutaali lähitaistelu, jonka valkoiset voittavat. Valkoista ratsuväkiosastoa johtava upseeri puhuu riviin kootulle antautuneiden punaisten ryhmälle: "Olette syyllistyneet rikoksista pahimpaan, maanpetokseen. Isänmaan nimessä tuomitsen teidät kuolemaan." Huomattavaa on, että punaupseeri Kiljunen (Tommi Korpela), joka onnistuu pakenemaan teloituspaikalta ammunnan alkaessa, on vain hetkeä aiemmin ampunut uhmakkaasti aseensa ja punaisen käsivarsinauhansa pois heittävän ja pakenemaan aikovan alaisensa. Pikateloituksia järjestetään puolin ja toisin, ja kohteeksi voi joutua vihollisen ohella oma rintamakarkuri tai muu "petturi". Myöhemmin Kiljunen vastaa kihlatulleen, opettaja Linnulle (Minna Haapkylä) itseään siviilien tappamista koskevista syytöksistä: "Ei sisällissodassa ole siviilejä. Ne olivat ihmisiä, jotka myrkyttivät tovereitaan. Sama kai se on ampuuko itse vai hakeeko lahtarikaartin paikalle ampumaan." Kihlattu vastaa: "Ei ole. Moraalisesti ei ole." Kiljunen: "No, mutta sellaista se sota oli. Kaikki sodat on." Kiljunen siis yhtäältä korostaa sisällissodan erikoisluonnetta, toisaalta hän väittää kaikkien sotien olevan samanlaisia.

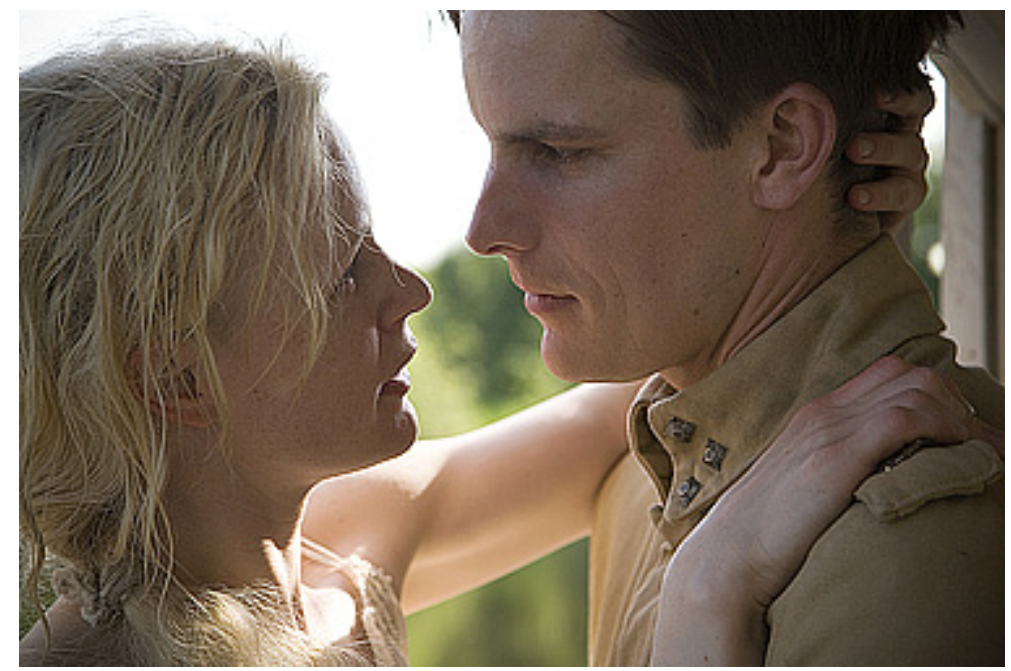

Raja 1918 on sisällissotaan sijoittuva kolmiodraama. Kuva: Border Productions Oy / FS Film Oy. 
Ohjaaja Louhimies (s. 1968) toteaa puolestaan Käsky-elokuvastaan, että hänen sukupolvensa on ensimmäinen, joka voi tutkia (sic) sisällissotaa ilman poliittista painolastia ("Kulissien takana", 2008). Hän jatkaa ristiriitaisesti: elokuva kertoo kuitenkin "enemmän voittajista ja voitetuista, vangitsijoista ja vangituista, kuin punaisista ja valkoisista" (ibid.). Toisin sanoen Louhimies näyttää ajattelevan niin, että historiallinen etäisyys auttaa tarkastelemaan Suomen sisällissotaa kiihkottomasti, ilman poliittista painetta, mutta samalla tämä tarkoittaa sisällissodan historiallisten erityispiirteiden sivuun työntämistä yleishumaanien valta-asetelmien tieltä. ${ }^{6}$ Ajatus on siis ristiriitainen mutta ymmärrettävä: elokuva ei halua suoraan "valita puoltaan", vaikka sen sympatiat ovat väistämättä, sen tarinasta johtuen, punaisten puolella. Raja 1918:n käsikirjoittanut ja Käskyn tuottanut Aleksi Bardy sekä Käskyn ohjaaja Louhimies myönsivät toisaalla, että he samastuvat enemmän sodan hävinneen osapuolen asemaan ja kritiikki on luonnollisempaa kohdistaa voittajaan (Eerola 2009, 84).

Marko Tikka $(2004,13)$ tiivistää sisällissodan käsittelyn valtavirran seuraavasti: "Sisällissota oli sekava tapahtumasarja, jonka ymmärtämiseen kukaan ei halunnutkaan pyrkiä [...] tärkeintä oli rakentaa omista uhreista myytti ja projisoida sotaan liittyvä pahuus oman ryhmän ulkopuolelle." Tikka puhuu ensi sijassa sodan jälkeisistä vuosista, mutta se voidaan laajentaa yleiseen tendenssiin keskittyä sodan aikana ja sen jälkeen tapahtuneisiin kauheuksiin: sisällissodan tapahtumat ja seuraukset peittävät alleen syyt ja sen alkamisen. Tämä pätee Pohjantähteä lukuun ottamatta artikkelissa käsiteltyihin elokuviin. Sota on, Tikan sanoin, "typistetty uhrinäkökulmaan", ja täten historiallinen tapahtuma on "mystifioitu" (Tikka 2004, 16).

Sisällissotakuvauksia analysoitaessa on syytä pitää mielessä Grindonin (1994, 223-225) varsin provokatiivinen väite historiallisesta elokuvasta ennen kaikkea poliittisena lajityyppinä. Tämä johtuu hänen mukaansa siitä, että toimiessaan sosiaalisena muistina historiallinen elokuva pyrkii assosioimaan yksilön suurempiin toimijoihin kuten valtioon, sekä henkilöt laajempiin, henkilöimättömiin historiaa muokkaaviin, perusluonteeltaan poliittisiin voimiin. Tämä pätee myös tässä artikkelissa käsiteltyihin elokuviin.

Louhimiehen edellä siteeratun ristiriitaisen näkemyksen (poliittisesti intohimoista vapaa tulkinta - periaatteessa universaali tarina ihmisten kohtaloista sodan ja tappamisen keskellä) kannalta on huomattavaa, että Käskyn taustalla olevan romaanin kirjoittaneen Leena Landerin mukaan tarinan inspiraatio tuli Jugoslavian 1990-luvun sisällissodasta ja siitä syntyneistä pohdinnoista ihmisten kohtaloista. Lopulta Lander päätyi miettimään Suomen sisällissotaa ja sen verrattaista läheisyyttä nykyhetkeen. Mielenkiintoiseksi Suomen sisällissodan teki hänelle myös se, että Suomessa oli myös naissotilaita. Ohjaaja Louhimies taas kertoo, että hän oli aina halunnut tehdä elokuvan Suomen sisällissodasta ja että Landerin romaani oli siihen erinomainen mahdollisuus. ("Kulissien takana", 2008.)

2000-luvun elokuvien sisällöllisten ratkaisujen painotukset havaittiin aikalaiskritiikissä: muun muassa Suomen Kuvalehden arviossa todettiin, että "uusien sisällissotaelokuvien linjaan kuuluu varovaisen tasapuolinen epäpoliittisuus. Käskyn sota näyttäytyy darwinistisena eloonjäämis- ja lisääntymiskamppailuna." (Sit. Eerola 2009, 69.) Muissakin arvioissa Käskyä pidettiin historiattomana elokuvana, joka vain sattuu sijoittumaan Suomen sisällissotaan (ibid.). Ensin mainittu argumentti - "varovaisen tasapuolinen epäpoliittisuus" - on kuitenkin kumottavissa jo sillä, että tarkastelemani elokuvat (Koivusalon Pohjantähdet olivat vasta valmistumassa) sijoittuvat sodan loppuvaiheeseen,
6 Myös Suomen hauskimman miehen ohjaaja Heikki Kujanpää (2018) kirjoittaa elokuvan mediatiedotteessa, että elokuvan yksi tavoite on tuoda lisää ymmärrystä "Suomessa yhä vallitsevasta kahtiajaosta ja sen seurauksista". Toisaalta elokuvan tarina on hänen mukaan universaali ja ajaton. 
jossa valkoiset ovat voitokkaita teloittajia ja punaiset epätoivoisen eloonjäämiskamppailun syövereissä, mutta sodan raakuus on elokuvissa kyllä sinänsä hyvinkin "darwinistista".

Elokuvia - jälleen poikkeus on Pohjantähti - leimaa haluttomuus pohtia sisällissodan syitä. Joka tapauksessa kaikissa manituissa kommenteissa korostuu edellä esiin nostamani Salmen argumentti historiallisen elokuvan peruspiirteestä: ne kertovat ensi sijassa tuotantoaikansa yhteiskunnasta ja kulttuurista, eivät siitä menneisyydestä, johon niiden tarina ja tapahtumat sijoittuvat.

\section{Historiallinen tieto ja ekstradiegeettisyys}

Jos elokuvat kertovat siis enemmän omasta tekohetkestään kuin menneisyydestä, mutta ovat samalla kertomuksia historiasta, on tarkasteltava, millaista historiallista informaatiota elokuvat tarjoavat katsojilleen sisällissodasta kertomiensa tarinoiden evästeeksi. Tämä on tärkeätä minkä tahansa historiallisen elokuvan kohdalla, mutta erityisen tärkeätä se on suomalaisessa yhteiskunnassa edelleen merkittävän historian aiheen tapauksessa.

Kuten Salmi (1993, 232-234) toteaa, historiallisen elokuvan keskeinen keino osoittaa historiallisuutensa on historiallisten koordinaattien antaminen katsojalle sen sijaan, että elokuvan voisi pelkän lavastuksen ja puvustuksen avulla olettaa sijoittuvan menneisyyteen. Tällaisia keinoja ovat elokuvan aloittaminen ekstradiegeettisillä teksteillä, jotka kertovat, mihin aikaan ja paikkaan elokuva sijoittuu. Toinen tyypillinen keino on ekstradiegeettisen kertojaäänen käyttö. Elokuvan tarinamaailman ulkopuolisina elementteinä niiden tehtävä on vakuuttaa katsoja elokuvan historiallisuudesta.

Raja 1918 alkaa seuraavalla ekstradiegeettisellä teksti-informaatiolla katsojan johdattamiseksi sisällissodan historiallisiin koordinaatteihin:

Ensimmäinen maailmansota runtelee Eurooppaa. Venäjän keisarikunnan romahdettua Suomi julistautuu itsenäiseksi 6. joulukuuta 1917. Tammikuussa 1918 alkaa punaisten kapina maan hallitusta vastaan. Kapina muuttuu sisällissodaksi, valkoiset punaisia vastaan, veli veljeä vastaan. Valkoisen hallituksen joukkoja johtaa entinen tsaarin kenraali Mannerheim. Saksa tukee sodan valkoista osapuolta.

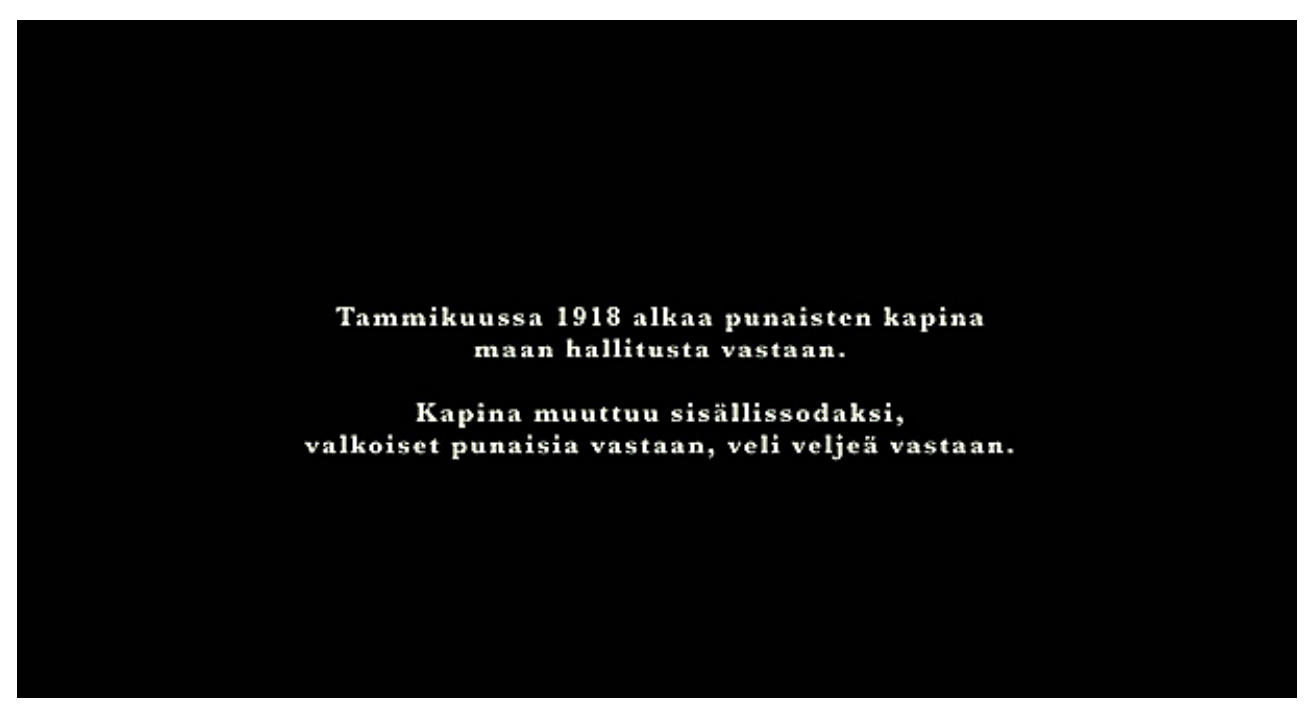

Raja 1918 kertoo sisällissodasta kuvaruututekstein. Kuvakaappaus DVD:Itä. 
Teksti taustoittaa sisällissodan Venäjän keisarikunnan romahdukseen, tosin bolsevikkien vallankumousta mainitsematta, sekä Suomen itsenäisyysjulistukseen. Huomattavin asia katsojan historialliseen tilanteeseen johdattavassa tekstissä on, että vain valkoisesta osapuolesta annetaan tarkempaa tietoa: on valkoinen hallitus, jonka joukkojen komentaja on Mannerheim, epäilemättä kaikkien suomalaisten tuntema historiallinen henkilö. Lisäksi katsojalle kerrotaan, että Saksa tukee valkoisia. ${ }^{7}$ Punaisista ei kerrota muuta kuin se, että he nousevat kapinaan Suomen hallitusta vastaan, mikä johtaa sisällissotaan.

Raja 1918 ilmestyi 2000-luvun sisällissotaelokuvista ensimmäisenä. Tuolloin elokuvan tekijät ovat aluksi selvästi uskoneet Suomen sisällissodan olevan itsessään katsojien mielenkiinnon herättävä aihe. Siksi on mielenkiintoista vertailla toisiinsa elokuvan teaseria ja traileria, eli kahta elokuvan markkinoinnille keskeistä artefaktia. ${ }^{8}$ Koska noin kaksiminuuttinen traileri on lähes puoli minuuttia pidempi kuin teaser, ja se on ilmiselvästi tehty myöhemmin, on loogista, että siinä esitellään elokuvan tarina käytännössä kaikkine keskeisine käänteineen. Historiaan traileri kuitenkin viittaa minimaalisesti.

Teaserin pääpaino on puolestaan historiassa ja se sisältää jopa arkistofilmiä sisällissodasta. Katsoja johdatetaan elokuvan historialliseen kohteeseen runsaalla tekstien käytöllä Venäjän lokakuun 1917 vallankumouksesta Suomen itsenäisyysjulistuksen kautta vuoden 1918 Suomen sisällissotaan. Neljäs teksti viittaa puolestaan elokuvan tarinaan: "Ylipäällikkö Mannerheim lähettää upseerin perustamaan rajaa Suomen ja Neuvosto-Venäjän välille". Huomionarvoista tässä on, että neljäs teksti asetetaan ikään kuin rinnakkaiseksi suurten kansallisten mullistusten kanssa. Elokuva haluaa vakuuttaa katsojansa historiallisuudestaan. Elokuvan tarina, joka on trailerin perusta lukuisine kohtauksineen, on teaserissa toisarvoinen, joskin elokuvan keskushenkilöiden välinen kolmiodraama nostetaan ymmärrettävästi esiin. Ehkä elokuvan lopullinen versio painottui vähemmän sisällissotaan kuin tekijät olivat suunnitelleet. ${ }^{9}$

Taistelu Näsilinnasta 1918 tarjoaa puolestaan katsojalle seuraavan informaation elokuvan tarinan seuraamisen evästeeksi. Kyseessä on elokuvan avauskohtausta seuraava, television historiadokumenttien tyyliä mukaileva osio, jossa kuvituksena on mustavalkoista arkistofilmiä tukinuitosta. Kertojaääni:

28. tammikuuta 1918 syttyi sisällissota vastaperustetussa Suomen tasavallassa. Maa jakautuu porvarilliseen valkoiseen ja sosialistiseen punaiseen osaan. Carl Gustav Mannerheim nimitetään valkoisen armeijan päälliköksi.

Ensimmäistä maailmansotaa käydään neljättä vuotta. Yliluutnantti Melin ja muut jääkärit palaavat Saksasta ja nousevat maihin Vaasassa 25. helmikuuta.

Maaliskuun 15. päivänä Mannerheimin valkoinen armeija ryhtyy hyökkäykseen punaisia vastaan Suomen eteläosissa. Kaksi päivää myöhemmin Melinin komppania lähtee Vaasasta kohti etelän rintamaa. Punaisten joukot vetäytyvät asteittain Tamperetta kohti. 26. maaliskuuta valkoinen armeija on Mannerheimin johdolla saartanut punaisen Tampereen.

Katsojan historialliseen tilanteeseen johdattavassa voice over -kerronnassa on kaksi erittäin huomionarvoista seikkaa: ensinnäkään sisällissodan syttymiselle ei kerrota mitään syytä. Sisällissodan syttymisen seurauksena Suomi vain jakautuu kahteen osaan. Toisekseen on huomioitavaa, että Mannerheim mainitaan katkelmassa peräti kahdesti valkoisen armeijan komentajana, mutta punaisille - vrt. "valkoinen armeija" - ei nimetä mitään johtajaa ja osapuoli kuvataan passiivisena sodan vastaanottavana osapuolena: ensin sota vain
7 Elokuva korostaa Saksan roolia sisällissodassa ja sen jälkeen. Saksan tappio päätti vasallisuhteelta vaikuttavan yhteistyön. Sama piirre on vahva myös Suomen hauskimmassa miehessä.

8 Kuten Salmi (1996, 14-15) kirjoittaa, trailereita ei olla useinkaan hyödynnetty elokuvatutkimuksessa, vaikka niistä käy ilmi, mitä elokuvantekijät ovat halunneet yleisöille elokuvasta nostaa esiin ja minkä he ovat uskoneet puhutelleen potentiaalisia katsojia. Salmen tekstin julkaisun jälkeen, eli DVD- ja internetaikakaudella trailerit ovat tulleet aivan uudella tavalla saataville. Ks. myös Mähkä 2016, 92, 94-95, 100-101.

\section{Elokuva perustuu alkupe-} räisidealtaan Jörn Donnerin isän, joka toimi vuonna 1918 vastaavassa tehtävässä kuin elokuvan von Munck, päiväkirjaan. Ohjaaja Törhösen mukaan ajatus elokuvasta periytyi vuodelle 1986, mutta elokuvaan päätyi vain pieniä osia päiväkirjamerkinnöistä ja sen seurauksena elokuvasta tuli aivan erilainen kuin Donnerin päiväkirjan pohjalta olisi syntynyt. ("Näin tehtiin Raja 1918", 2007.) 


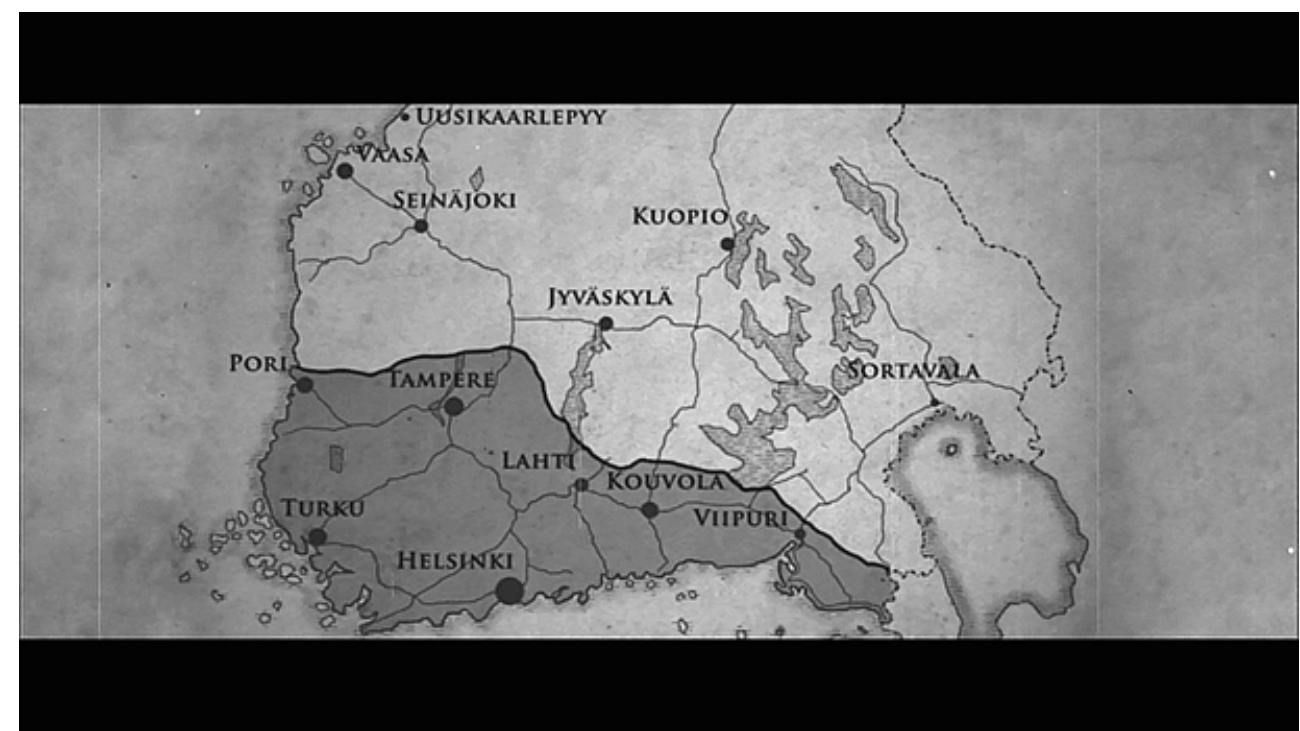

Arkistofilmiä käytetään fiktioelokuvassa vahvistamaan kerrotun tarinan historiallista uskottavuutta elokuvassa Taistelu Näsilinnasta 1918. Kuvakaappaus DVD:Itä.

syttyi ja sitten valkoiset hyökkäävät. Mannerheimin keskeisyyttä lisää narraatiota seuraavien elokuvan alkutekstien taustalla nähtävä arkistofilmi, jossa Mannerheim on näkyvästi esillä.

Taistelu Näsilinnasta 1918 kertoo katsojalle myös, että "Elokuva perustuu Suomen v. 1918 sisällissodan todellisiin tapahtumiin Melinin komppanian sotilaiden kertomana" ${ }^{10}$ Muutama sotilaista toimii elokuvassa Melinin komppanian tapahtumia kuvaavana kertojana, mutta valtavirranelokuvalle hyvin poikkeuksellisella tavalla: he kertovat vuorollaan tapahtumista kameraan katsoen ja saattavat välillä hätkähtää läheltä viistävää luotia. Sotilaat liikkuvat diegeettisten rooliensa ja ekstradiegeettisyyden välillä kommentoidakseen tapahtumia, joita elokuvassa ei näytetä. On perusteltua olettaa, että juuri nämä sotilaiden kertomukset perustuvat elokuvan alussa mainittuun haastattelumateriaaliin, ja kerronnallisen ratkaisun tarkoitus on epäilemättä lisätä elokuvan historiallista arvovaltaa, vaikka se on valtavirran näytelmäelokuvalle epätyypillinen, mimeettistä todellisuusilluusiota rikkova elementti. Tämän tekniikan käyttö yleistyy elokuvan edetessä. ${ }^{11}$

Käsky taustoittaa historiaa tarinansa seuraavin kuvatekstein: "Suomen sisällissota, huhtikuun loppu 1918. Valkoiset voittajat etsivät jäljelle jääneitä punaisia. Punaisten puolella taisteli 2000 naissotilasta." Nämä ovat siis ne ajallis-temaattiset koordinaatit, joiden saattelemana katsoja alkaa seurata elokuvan tarinaa, eikä sen seuraaminen muuta edellytäkään. Huomionarvoista kuitenkin on, miten sodan alkamista ei taustoiteta tai muuten kommentoida lainkaan. Se nimeää sisällissodan osapuolet valkoisiksi ja punaisiksi, mutta ei sen enempää luonnehdi niitä, kuten Näsilinnan teksti, joka määrittää osapuolet "sosialistiseksi" ja "porvarilliseksi". Tässä mielessä yllä siteerattu Suomen Kuvalehden näkemys on osuva, Käskyn tekijät jättävät määrittelyt ja sodan taustan pohtimisen katsojalle.

Kaikki artikkelissa käsitellyt elokuvat pyrkivät luomaan uskottavan historiallisen epookin sisällissodasta. Niiden visuaalinen historiallinen uskottavuus perustuu lähteisiin, joita sisällissodasta ovat erityisesti valokuvat. Sodanaikaisiin valokuviin sekä viitataan elokuvallisesti että niitä käytetään elokuvissa.
10 Elokuvan alkuteksteissä mainitaan käsikirjoittajien kohdalla, että käsikirjoitus "perustuu Konrad Vestlinin v. 1936 tekemiin haastatteluihin".

11 Tekniikka voidaan ymmärtää "brechtiläisenä" katsojan samastumista estävänä elementtinä, joka muistuttaa Peter Wollenin vastaelokuvan käsitettä (ks. Mähkä 2017). Siinä missä Brechtin ja vastaelokuvan tarkoitus on saada katsoja "vieraantumaan" lavalla/valkokankaalla esitetystä fiktiosta, Näsilinna-elokuvan tekijöiden tarkoitus on rinnakkainen: tehdä elokuvan historiakuvaus uskottavaksi viittaamalla sen perustumiseen tapahtumissa mukana olleiden inmisten haastatteluille. 
Käsky alkaa nopeilla leikkauksilla nuoresta naisesta, joka leikkaa tukkaansa lyhyemmäksi peilin edessä. Viimeisessä kuvassa hän poseeraa valokuvastudiossa punakaartin univormussa ylpeänä kivääri olalla. Samanlaisen mutta sisällöllisesti paljon hallitsevamman viittauksen sisällissodasta tunnettuihin kaartilaisten poseerauskuviin sisältää Taistelu Näsilinnasta 1918.

Historiallista faktuaalisuuttaan korostavan elokuvan alkutekstijaksossa käytetään mielenkiintoista tehokeinoa: valkoisen armeijan harjoittelua kuvaavien mustavalkoisten arkistofilmien päälle leikataan valokuvia punakaartilaisista, jotka on sävytetty punaisella - varsinkin punainen käsivarsinauha nousee esiin kuvista. Elokuva on siinä mielessä poikkeuksellinen sisällissotaelokuva, että se kertoo tapahtumista kokonaan valkoisten näkökulmasta ja punaiset on etäännytetty vastapuoleksi - tätä asetelmaa korostaa myös mainittu tyylillinen ratkaisu, jossa punakaartilaiset on selkeästi erotettu esittämällä heidät valokuvina, kun taas valkoiset esiintyvät liikkuvassa kuvassa historiallisissa filmikatkelmissa. Kuitenkin valokuvat punaisista hallitsevat visuaalisesti alkutekstijaksoa, ja valkoiset jäävät pääosin persoonattomiksi taustalla liikkujiksi.

Punaiset todellakin esiintyvät alkutekstiosiossa valokuvissa poseeraten - osa poseerauksista on erittäin tyyliteltyjä, jopa dandymaisia - kun taas valkoiset näyttäytyvät arkistofilmeissä tekemässä jotain sotilaalle arkipäiväisempää, kuten taisteluharjoituksissa tai marssilla. Vaikutelma on, että punakaarti on ikuistettu historiaan sarjaksi liikkumattomia, itsevarmoja potretteja. Tämä on ymmärrettävissä siten, että koska punainen Suomi lakkasi olemasta olemassa sisällissodan seurauksena, ja koska Suomi jatkoi valtiona toiseen maailman-
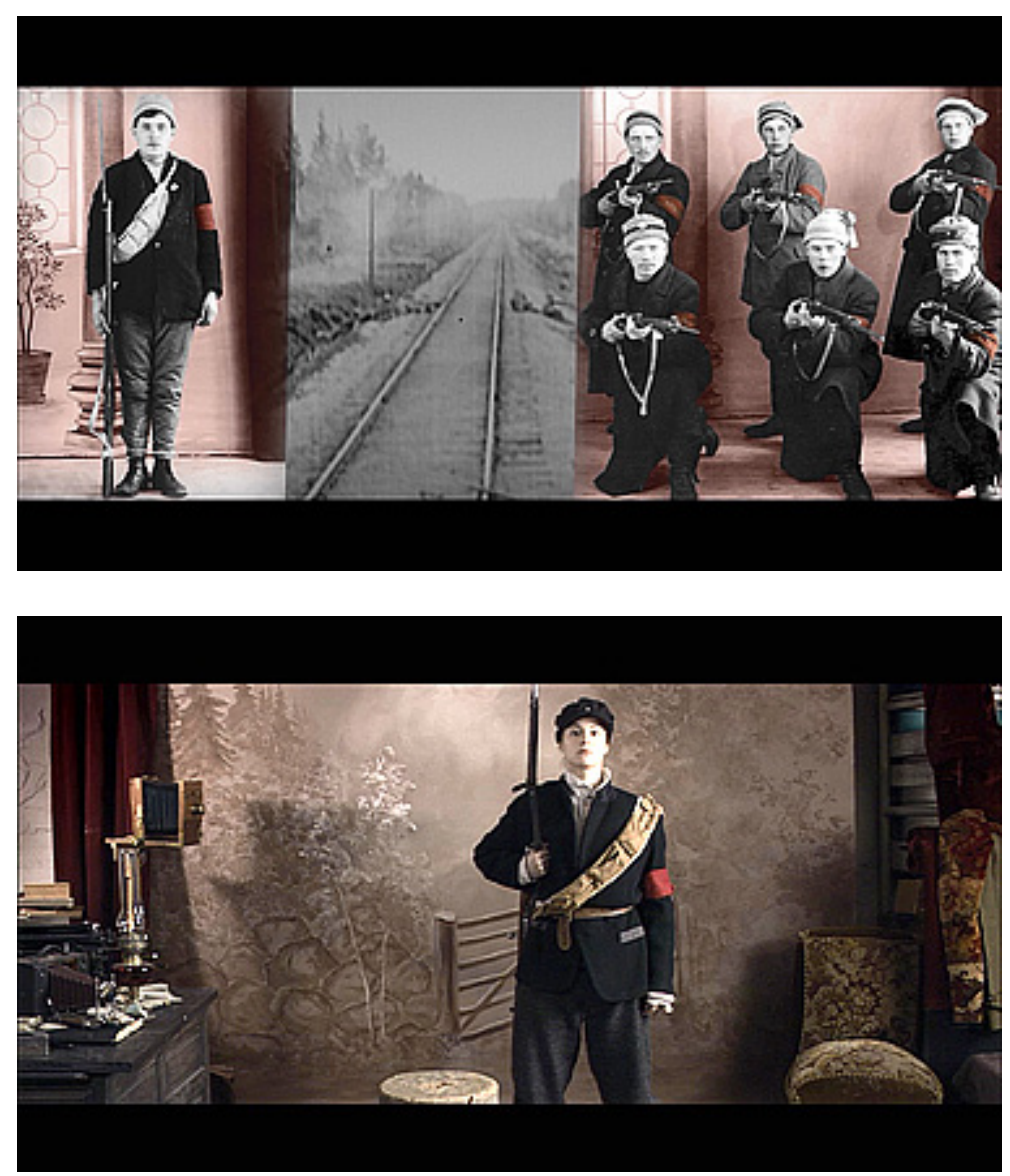

Sisällissotaelokuvissa sekä hyödynnetään arkistovalokuvia (Taistelu Näsilinnasta 1918, ylh.) että viitataan niihin (Käsky, alh.). Kuvakaappaukset DVD:Itä. 
sotaan "valkoisena" Suomena, punaisten vallankumousyritys motiiveineen on aiheena jäänyt viime vuosikymmeninä sisällissodan muiston marginaaliin, Pohjantähteä lukuun ottamatta: vallankumouksen pohtimista ei olla syystä tai toisesta pidetty mielekkäänä tai kiinnostavana. Sodan kuvaa hallitsee sen loppuvaihe ja erityisesti punaisten kohtalo valkoisten käsissä.

Taistelu Näsilinnasta 1918 myös päättyy autenttisiin valokuviin sisällissodasta, selvästikin dokumentaarisuuttaan korostaakseen, mutta mukana on myös selkeä katsojan tunteisiin vetoamisen motiivi. Kun valkoiset ovat vallanneet elokuvan lopussa Näsilinnan, elokuva korostaa taistelun verisyyttä kuvaamalla pihalla makaavia kaatuneita. Tapahtuman lavastuksen autenttisuutta vahvistetaan leikkaamalla historialliseen - tai ainakin sellaiselta näyttävään - valkokuvaan vallatusta Näsilinnasta. Pihalla on vieläkin enemmän ruumiita kuin elokuvan otoksessa. Tätä seuraa sarja traagisia arkistovalokuvia kuolleista lapsista, ruumisröykkiöistä eri puolilta sisällissodan taistelukenttiä sekä teloituksista. Elokuvassa eräs valkoisista on aiemmin todennut, että ruumiisiin on niin tottunut, ettei niihin ei edes enää kiinnitä huomiota, ellei kyseessä ole tuttu. Elokuvan arkistovalokuvien avulla katsojassa hakema efekti on päinvastainen. Samalla valokuvat toimivat ekstradiegeettisenä kerrontamenetelmänä, joiden tehtävä on lisätä elokuvan historiallista uskottavuutta.

\section{Valkoinen mies ja punainen nainen sisällissodan osapuolina}

Elokuvissa punaiset ja valkoiset ovat lähtökohtaisesti "annettuja" osapuolia (jälleen "Pohjantähdet" ovat poikkeus). Osapuolet vain "ovat olemassa", ja tämä liittyy edelleen suomalaisessa yhteiskunnassa olemassa oleviin identiteetteihin. ${ }^{12}$ Taistelu Näsilinnasta 1918 -elokuvan mainosjulisteessa on mielenkiintoinen yksityiskohta: etualalla on kaksi miestä, valkoisten komppanianpäällikkö Melin (Nicke Lignell) sekä punakaartilainen, molemmat pistooli kädessä. Melin esiintyy kuvassa ilman valkoista käsivarsinauhaa, mikä selittyy sillä, että hän toimii ilman kyseistä tunnusmerkkiä itse elokuvassakin. Entä kuka on kuvan punainen? Hän on Näsilinnan hetkellisesti valkoisilta valloittavan punakaartiosaston päällikkö. Hän esiintyy elokuvassa yhdessä otoksessa, ja hänellä on vain pari vuorosanaa. Miksi näin pienessä roolissa oleva hahmo on nostettu lähes yhtä näkyvään osaan julisteessa kuin elokuvan keskushenkilö, vaikka Melinin hahmo julisteessa onkin suurempi ja hallitsevampi? Epäilemättä siksi, sisällissotaelokuvassa osapuolet määrittävät toisensa. Tämä ei tarkoita sitä, että elokuva samastuisi valkoisiin, päinvastoin: elokuva esimerkiksi kuvaa vain valkoisten julmuuksia, kuten vankien teloituksia.

Tarkastelemissani elokuvissa valkoista osapuolta edustavat viitteellisinä, ja Pohjantähden tapauksessa konkreettisina, ryhminä porvarit, maanomistajat ja koulutettu väestönosa, mukaan lukien papisto. Pessimistisin kuvaus valkoisesta eliitistä on Käskyn sotatuomari Hallenberg (Eero Aho), "viisas mies, kirjailija ja humanisti", joka tunnetaan oikeudenmukaisuudestaan. Hallenbergistä on kuitenkin tullut paatunut kuolemantuomioiden jakaja, joka omien sanojensa mukaan "tappaa ilman katumusta".

Konkreettisesti valkoinen osapuoli määrittyy kuitenkin elokuvissa sotilaiden kautta. Sekä Käskyn jääkäri Harjula että Raja 1918:n kapteeni von Munck edustavat elokuvissa valkoisten sotilaiden parhaimmistoa. Vaikka kumpaakaan ei näytetä varsinaisissa taistelutoimissa, kummankaan rohkeutta tai pätevyyttä sotilaina ei kyseenalaisteta millään tavoin. On syytä huomata,
12 Taistelu Näsilinnasta 1918:n valkoiset ovat ruotsinkielisiä pohjanmaalaisia. Kirjailija Kjell Westön mukaan suomenruotsalaiset on pitkälti "häädetty" sisällissodan historiasta. Heidät on oletettu valkoiselle osapuolelle, "porvareiksi", vaikka "kapinan" johdossa oli muitakin ruotsinkielisiä kuin kansavaltuuskunnan Edvard Gylling. (Salminen 2007, 206.) 


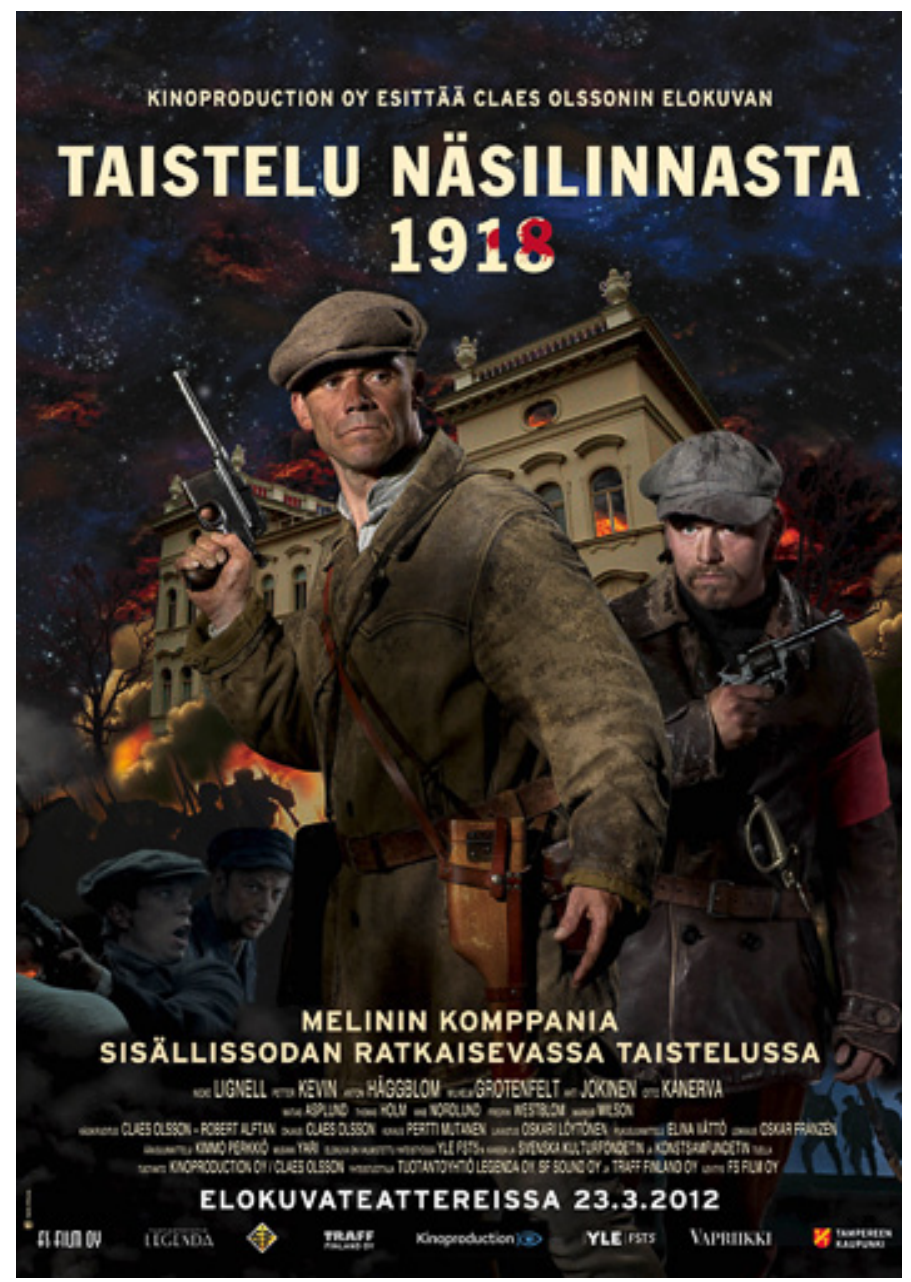

Sisällissotaelokuvassa sodan osapuolet määrittävät toisiaan. Mainosjuliste. Kuva: Kinoproduction Oy / FS Film Oy.

että jääkärit ja valkoiset upseerit laajemmin edustavat elokuvissa myös "lahtariutta" puhtaimmillaan, ja heidät liitetään usein myös suoraan fasismiin.

Raja 1918:ssa Munckin lähin alainen, luutnantti Suutari (Lauri Nurkse), teloittaa innokkaasti venäläisiä ja punaisiksi epäilemiään suomalaisia. Hän ampuu myös Munckin rakkauden kohteen tämän organisoitua punavankien joukkopaon karanteenista. Pohjantähden keskeisin valkoinen sotilas on kirkkoherran poika, jääkäriluutnantti Salpakari (Antti Luusuaniemi), joka johtaa Pentinkulman punaisten teloituksia jämäkällä otteella. Hänet palkitaan kirkon alttarilla "kiitollisen Suomen kansan" toimesta. Arvattavasti tilaisuudessa "kansaa" edustavat vain paikallinen herrasväki ja Suojeluskunta. Valkoista armeijaa edustavat siis sekä konkreettisena että viitteellisenä ryhmänä jääkärit, vaikka he olivat lukumääräisesti pieni osa sisällissodan valkoista armeijaa. Tämä johtunee ensi sijassa siitä, että myöhempi historiankirjoitus on korostanut jääkärien merkitystä, myös itsenäisen Suomen puolustusvoimien ydinjoukkona.

Ketkä sitten edustavat elokuvissa punaisia? Vaikka elokuvissa on torppareita, työläisiä ja agitaattoreita, voi todeta, että 2000-luvun sisällissotaelokuvassa punaista osapuolta edustaa ennen kaikkea punakaarti, ja vielä erityisesti naispunakaartilaiset eli ilman kunnon sotilaskoulutusta rintamalle lähetetyt ihmiset. Suomen sisällissotaa onkin nimitetty "amatöörien sodaksi", jota kävivät kouluttamattomat joukot, mikä on tärkeä osaselitys sille, että valkoisia kuoli sodan alussa enemmän punaisten teloittamina kuin taistelukentällä. 


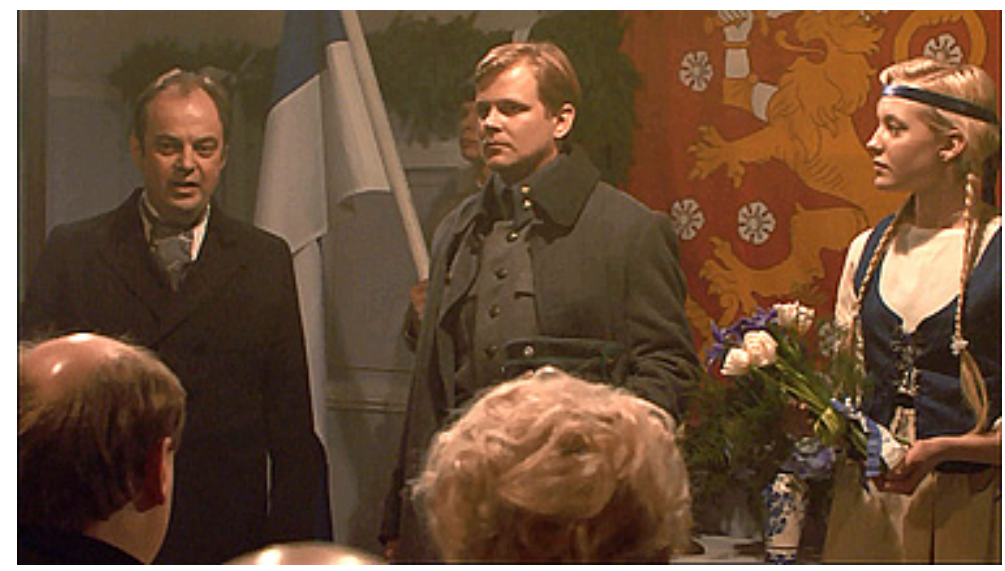

Punavankien

teloituksia

tarmokkaasti

johtava jääkäri-

upseeri saa

palkinnon "kiitol-

liselta Suomen

kansalta" elo-

kuvassa Täällä

Pohjantähden

alla. Kuvakaap-

paus DVD:Itä.

Valkoisille vasta jääkärien saapuminen antoi mahdollisuuden asiantuntevaan koulutukseen ja joukkojen organisointiin. Punaisille tällaista vahvistusta ei tullut, minkä vuoksi kaartin taistelukyky oli loppuun asti verraten heikko ja tappiot suuria. Aapo Roselius (2006, 151-160; "Kulissien takana" 2008; Hoppu 2009) suhteuttaa asian toteamalla, että ainoa suurempi ammattimainen sotilasjoukko Suomen sisällissodassa oli Saksan Itämeren divisioona. Elokuvissa punakaartin amatööriluonnetta alleviivataan esittämällä valkoinen armeija "oikeana" armeijana, mitä osoittaa esimerkiksi aiemmin esiin nostamani Taistelu Näsilinnasta 1918 -elokuvan alkutekstijakson ratkaisu esittää valkoinen armeija taisteluharjoitusfilmeinä ja punakaarti staattisina potretteina.

Punakaartin "amatöörimäisyys" nostetaan vahvasti esiin Koivusalon Pohjantähti-versiossa. Kapinaa vastustava Janne Kivivuori (Tapani Kalliomäki) viittaa punaisten olemattomaan sotilaskoulutukseen nimittämällä ivallisesti rakennusmestari Hellbergiä (Raimo Grönberg) tulevan kaartin "everstiksi" ja torppari Akseli Koskelaa (Ilkka Koivula) "sotaluutnantiksi". Kun Koskelan plutoona aikanaan saapuu rintamalle, tämä alkaa ymmärtää punakaartin puutteet. Hänen miehilleen luvattuja varusteita ei ole olemassa, ja kun hän johtaa ensimmäistä taisteluaan, hänen miehensä eivät tottele etenemiskäskyä ennen kuin hän itse hyökkää edeltä ("mene itte saatana!"). Koskelalla ei ole mitään todellista kontrollia joukkueeseensa, vaan nämä perääntyvät spontaanisti vastuksen kovetessa. Elokuva antaa punakaartista lohduttoman kuvan Koskelan joukkueen kautta.

Vaikka naispunakaartilaisten nostaminen sisällissodan ja erityisesti punaisen osapuolen muistelun etualalle onkin viime vuosikymmenien ilmiö, on huomattavaa, että elokuvassa heidän osuutensa nousi esiin jo Edvin Laineen vuoden 1968 Täällä Pohjantähden alla -filmatisoinnissa. Sodan loppuvaiheessa punaisten huoltojoukoissa työskentelevä nainen jakaa kiväärit naisillekin ja sivaltaa häntä estelevälle miehelle, että tässä ollaan, koska asioita ei hoidettu kunnolla alun perin. Miehen vastarinta loppuu siihen paikkaan. Koivusalon filmatisoinnissa Koskelan johtamaan pakolaisjoukkoon liittyneet naiset osoittautuvat kovemmiksi taistelijoiksi kuin suurin osa miehistä.

Punakaartin taistelutoimintaan osallistuneita naiskomppanioita nimitettiin "kuolemanpataljooniksi" Venäjän vallankumouksen esimerkin mukaisesti. Aiemmin naiskaartilaisiin oltiin suhtauduttu punaisten keskuudessa ja varsinkin siviilijohdossa usein penseästi, mutta sodan lopussa heidän sotimistaan käytettiin jo propagandakeinona ja sodan jälkeen osoituksena työväen yhtenäisyydestä vallankumouksen takana. (Piiroinen-Honkanen 2006, 38-42, 81-82, 
91-93.) On syytä olettaa, että esimerkiksi Käskyn naispunakaartilaiset ovat tällaisen taisteluyksikön rippeet. Oletusta vahvistaa myös heidän kohtalonsa. Valkoisten puolella, jotka eivät hyväksyneet omiin riveihinsä naistaistelijoita, asenteet naispunakaartilaisia kohtaan vaihtelivat ihmetyksen, vähättelyn ja suoran halveksunnan välillä. Heitä huoriteltiin ja kutsuttiin "ryssänmorsiamiksi" (Piiroinen-Honkanen 2006, 83-87), kuten Käskyn naisiakin.

Käsky korostaakin elokuvista vahvimmin punaisten naisten roolia: punainen Suomi määrittyy naiseksi, valkoinen Suomi mieheksi, mikä reflektoi sisällissodan muistelua ja historiantutkimusta 2000-luvulla. Siksi on ymmärrettävää, että jääkäri Harjula ei näytä ihmettelevän naispunakaartilaisia sinänsä: naispunakaartilaisten osuus ja kohtalot ovat olleet keskeisimpiä teemoja sisällissodan käsittelyssä viime vuosikymmeninä. Siksi fiktiivinen hahmo, Harjula, ei "osaa" ihmetellä naistaistelijoita, sillä elokuvan tekohetken eli 2000-luvun kontekstissa Suomen sisällissodan naistaistelijat ovat yleisesti tunnettu ja sisällissodan kokonaiskuvassa korostunut ilmiö. ${ }^{13}$

\section{"Tappion kulttuuri" ja Suomen sisällissota}

Käsky esittelee sodasta Suomen sisällissodasta 2000-luvulla yhä enemmän korostetun väki- ja mielivallan elementin, miesten naisiin kohdistaman seksuaalisen väkivallan ja alistamisen. Elokuvan alussa naispunakaartilaiset joutuvat valkoisten vangitsijoidensa viinanhuuruisten juhlien vastentahtoisiksi osallistujiksi. Valkoisten päällikkö, jääkäriluutnantti (Janne Virtanen), hakee vangitun punakaartilaisnaisen, Miinan (Pihla Viitala), ja raiskaa tämän. Tämän jälkeen hän katsoo naisen välttelevää katsetta arvioiden ja komentaa vielä joukon alaisiaan raiskaamaan tämän - kyse on äärimmäisestä nöyryyttämisestä ja väkivallasta. Raiskausta edeltänyt juhlien jakso on kuvattu käsivaralla, ja humaltunutta tunnelmaa säestää yhden valkoisista soittama epävireinen piano. Tämän kontrastina Miinan raiskaus kuvataan lähes staattisesti vain parista kuvakulmasta: vaihtuvien miesten kasvoista muodostuu lähikuvien irvokas sarja. Väliin leikataan Miinan vuoroin välinpitämättömiin ja tuskaisiin kasvoihin. Satunnainen väkivalta muuttuu systemaattiseksi. ${ }^{14}$

Koivusalon Pohjantähti-filmatisointi kuvaa myös vankileirien massateloituksia taisteluiden päätyttyä. Elokuvassa itkevät naisvangit marssitetaan joukkohaudan reunalle. Seuraa leikkaus konekiväärimiehiin, jotka niittävät naiset rutiininomaisesti monttuun. Sama otos on mukana jo Laineen Pohjantähti-elokuvassa (1968), joten tässä mielessä sisällissodan naisuhrit eivät

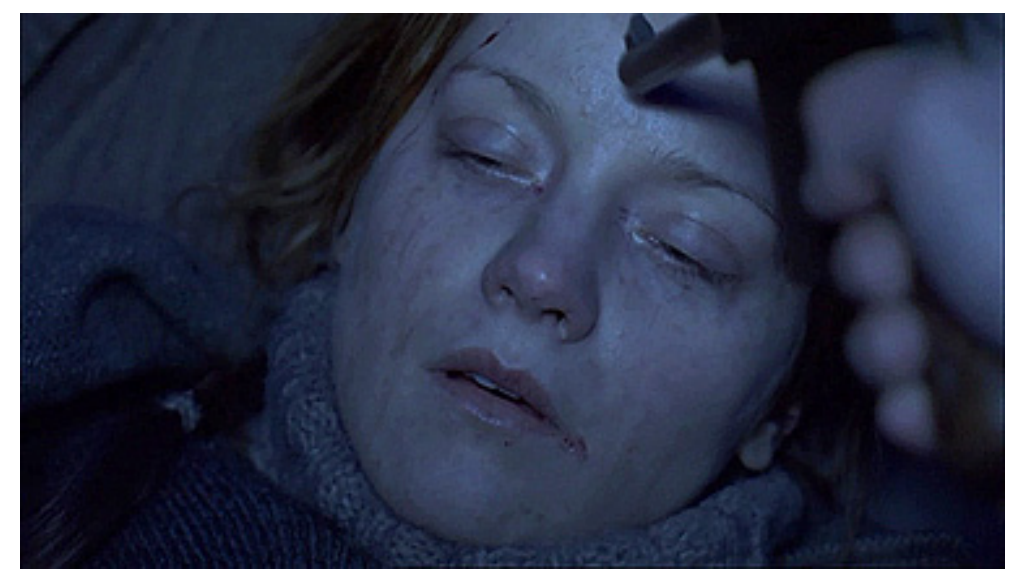

Naisvankien teloitus elokuvassa Täällä Pohjantähden alla. Kuvakaappaus DVD:Itä.
13 Naisten osuus punakaartin aseellisista joukoista oli 2-3 \%, alle 2000 henkeä (PiiroinenHonkanen 2006, 41-42).

14 Louhimiehen aiempien elokuvien tapaan seksuaalisuudella on elokuvassa merkittävä, jopa kerrontaa määrittävä rooli: Miinan joukkoraiskaus, Harjula masturboimassa, tuomarin ja Harjulan seksikohtaus, Miinan yritys tuomarin viettelemiseksi oman henkensä säästämiseksi, Harjulan ja tuomarin vaimon akti sekä Harjulan ja Miinan rakastelu. Viimeksi mainittua ei kuvata kuin ensikosketuksina, muissa tapauksissa seksiaktit kuvataan kiireettömästi ja estetisoiden. 
välttämättä ole aivan yhtä uutta tietoa suurelle yleisölle kuin viimeaikaisisten esitysten (esim. Liukkonen 2018) vastaanotto antaa ymmärtää. Vastaavasti Laineen elokuvassa näytetään, miten valkokaartin vääpeli käyttää palvelijanaan toimivaa naisvankia seksuaalisesti hyväkseen, kun taas Koivusalon versio kuvaa naispunavankien raiskaamista.

Käskyssä valkoisen puolen omatuntona toimiva Harjula toteaa Miinalle, että naiskaartilaisten raiskaaminen ja ampuminen oli väärin. Heidän dialoginsa elokuvassa muodostuukin pienistä katkelmista eristyksissä muista ihmisistä. Sodan vastapuolien dialogi on hapuilevaa, päämäärätöntä. Huomattavin ero on hahmoissa: vaikka Harjula on tilanteessa niskan päällä, hänen katseensa ja puheensa on välttelevää ja tietyllä tapaa anteeksipyytävää, kun taas Miinan olemusta leimaa läpi elokuvan intensiivinen, uhmakas katse. Tämä korostuu myös elokuvan promootiomateriaalissa, kuten mainosvalokuvissa ja elokuvajulisteissa: Miina katsoo haastavasti kameraan, kun taas Harjula katselee maahan tai etäisyyteen kuin häpeillen. ${ }^{15}$ Punaista Suomea naisena edustava Miina haastaa Harjulan edustaman valkoisen Suomen miehen sisällissodan raakuuksista.

Vaikka kaikissa käsittelemissäni elokuvissa (paitsi jälleen Pohjantähdessä, jossa tapahtumia kuvataan toisen maailmansodan jälkeiseen aikaan asti) tapahtumat päättyvät punaisten täydelliseen tappioon, niissä kaikissa enteillään tavalla tai toisella myös valkoisen Suomen myöhempää tuhoutumista ja työväenliikkeen ja sosialismin myöhempää menestystä. Tässä juuri punaisten kokemalla tappiolla on keskeinen merkitys. Wolfgang Schievelbusch (2004, 20-21, passim.) kirjoittaa "tappion kulttuurista" eli siitä, miten hävinnyt osapuoli omaksuu vakaumuksen, jonka mukaan se on tappion koitettua itse asiassa "edellä" voittajaansa. Hävinnyt ymmärtää, että voittajan ja hävinneen positiot vaihtelevat historiassa, kun taas voittaja vain paistattelee (sen hetkisessä) menestyksessään. Voitto on voittajalle "kirous", kun taas lyöty osapuoli kokee moraalisen puhdistautumisen. Asetelmassa toteutuvat antiikin hybriksen idea ja kristinuskon nöyryyden ideaali. ${ }^{16}$

Tämä ajattelu on läsnä myös Suomen sisällissodan myöhemmässä ymmärtämisessä: valkoisten voitto on tietyssä mielessä vain hetkellinen ja ohimenevä. Sisällissodan jälkeiset poliittiset reformit ovat tästä yksi esimerkki, Suomen tappion aiheuttama poliittinen käänne toisen maailmansodan jälkeen toinen. Janne Kivivuoren vihainen repliikki kuolemantuomioita jakavalle valkoisten tuomioistuimelle Täällä Pohjantähden alla -elokuvassa viittaakin tavallaan tulevaan, siis sen lisäksi, että aineetonta ei voi tappaa fyysisesti: "Pankaa vaan laidasta laitaan, sosialismi siinä jää kyllä tappamatta!"

Myös muissa elokuvissa viitataan valkoisten voiton väliaikaisuuden ideaan ja siihen, että punaisten asia tulee vielä jos ei voittamaan niin ainakin tavalla tai toisella toteutumaan. Raja 1918:ssa kapteeni Munck saa värvättyä sihteerikseen selvästi punaisten puolella henkisesti olevan naisopettaja Linnun, jonka motiivi on, että hän uskoo voivansa auttaa punaisia pakenemaan Venäjälle toimimalla virkailijana raja-asemalla. Munck ojentaa hymyillen kätensä opettajalle ja toivottaa tämän tervetulleeksi "Suomen valkoisen armeijan palvelukseen". Lintu vetää kätensä pois ja toteaa: "Ette te täällä kauan ole. Maailma on kyllästynyt rajoihin ja niistä johtuvaan väkivaltaan." Munck vastaa: "Kunpa olisittekin oikeassa, mutta valitettavasti olette väärässä." On selvää, että Munckin käyttämä ilmaus "Suomen valkoinen armeija" närkästyttää Lintua, ja tämä on hänen epäkohteliaisuutensa todellinen syy. Samalla hän esittää ennustuksen "valkoisen Suomen" lopusta, minkä elokuvan katsojat varmasti ymmärsivät.
15 Ks. tämän Lähikuvan numeron kansi.

16 Schievelbuschin esimerkkejä ovat muun muassa preussilaiset Ranskassa 1870-luvun alussa sekä Ranskan armeijan afrikkalaistaustaiset miehitysjoukot Reininmaalla ensimmäisen maailmansodan jälkeen. Esimerkeissä siviiliväestö naiset ja lapset - on miehittäjän mielivallan alla, mutta samalla ohjailee miehittäjää käyttäen älykkyyttään. Käskyn kohdalla tämä toteutuu siten, että Miina käyttää seksuaalisuutta hänet vanginneiden miesten manipulointiin. 
Käskyn loppu on Schievelbuschin "tappion kulttuurin" ajatuksen kannalta symbolisin ja ambivalentein. Armottomaksi teloittajaksi "kirjailijasta ja humanistista" muuttunut tuomari Hallenberg lohduttaa jääkäri Harjulaa: "Aaro, jälkipolvet tulevat muistamaan meidät sankareina." Voi olettaa, että kyseessä on viittaus valkoisen Suomen historiankirjoitukseen, jossa sodan jälkeisillä teloituksilla tulee olemaan pieni tai jopa olematon osuus. Hallenberg on kuitenkin niin voiton tunteesta nousevan hybriksen vallassa, ettei osaa kuvitella tilannetta, jossa muun muassa hänen toimensa tultaisiin tuomitsemaan. Elokuva kuitenkin viestittää, että näin ei ole, vaan se alleviivaa valkoisten tekemiä massateloituksia sisällissodan muistoa hallitsevana elementtinä.

Elokuvan lopussa Harjula auttaa Miinan pakenemaan ja ampuu samalla esimiehensä, elokuvan alussa Miinan raiskanneen jääkäriluutnantin. Valkoiset tappavat Harjulan välittömästi. Harjulaa rakastava Hallenberg hirttäytyy. Jääkärin asepuvusta riisuttu Harjulan ruumis heitetään symbolisesti punavankien sekaan joukkohautaan. Seuraavassa kohtauksessa valkoiseen käsivarsinauhaan pukeutunut Miina, joka kantaa kohdussaan omien sanojensa mukaan "lahtarin äpärää", menee valkoisten hallinnoimaan orpokotiin ja hakee teloitetun toverinsa pojan kasvatikseen esiintyen tämän tätinä. Miina toteaa pojalle: "Me huijattiin niitä oikein kunnolla," mihin poika hymyilee ja nyökkää. Elokuva päättyy romanttiseen montaasijaksoon, jonka aikana poika hyräilee "Kansainvälistä". Käsky implikoi, että punaiset olivat lopulta sodan vähintään moraalisia voittajia. Pohjantähtiä lukuun ottamatta muut artikkelissa käsitellyt elokuvat eivät sisällä samaa viestiä, mutta ne eivät kyseenalaistakaan sitä. Tämä juontuu osin elokuvien sisällissodan loppuun sijoittumisesta.

\section{Valkoisen ja punaisen Suomen muistot}

Elokuvissa sisällissodan julmuutta kuvataan myös lasten kokemusten kautta, mikä viittaa samalla sodanjälkeisten sukupolvien muistoihin. Käskyssä Harjula laittaa pojan orpojen kuljetukseen ja ilmiselvästi valehtelee pojalle, että tulee aikanaan hakemaan tämän orpokodista. Pohjantähdessä Akselin lapset tulevat väistämättä tietoisiksi setiensä teloituksista sekä isänsä tuomiosta. Taistelu Näsilinnasta 1918 sisältää aitoja valokuvia kuolleista lapsista sekä lapsista katsomassa ruumiita.

Kaikkein groteskeimmat näytellyt otokset ovat Raja 1918 -elokuvassa. Koulussa poikaoppilas huutaa ivallisesti: "Punikit joutuu Tammisaareen ammuttaviksi niin kuin Ilmarin isä!" ${ }^{17}$ Elokuvan alussa lapset jäävät sotivien osapuolten jalkoihin ja joutuvat raa'an lähitaistelun todistajiksi. Munck puolestaan näkee ryhmän lapsia leikkimässä teloitusta: viisi poikaa seisoo rivissä pellolla puukivääreineen. Heillä on valkoiset käsivarsinauhat. Yksi pojista seisoo, punaisine käsivarsinauhoineen, ja kaatuu poikien "ampuessa". Otos implikoi, että pojat ovat joko nähneet teloituksen tai kuulleet sellaisesta tarpeeksi yksityiskohtia, jotta makaaberi "sotaleikki" näyttää autenttiselta. Teloitukset ja vankileirit ovat sisällissodan hallitseva muisto, täysin ymmärrettävästi.

Elokuvat viittaavat eri tavoin sisällissodan jälkeiseen Suomeen. Miten ne käsittelevät sitä eksplisiittisesti? Elokuvista vain Raja 1918 ja Täällä Pohjantähden Alla II kuvaavat sisällissodan jälkeistä valkoista Suomea. Ensin mainitussa korostetaan Suomen saksalaissuuntautuneisuutta ja Saksan vaikutusvaltaa ensimmäisen maailmansodan viimeisinä kuukausina. Itse asiassa Suomi näyttää toimivan elokuvassa Saksan sanelupolitiikan mukaan esimerkiksi Neuvosto-Venäjän vastaisen rajan sulkemisen suhteen. ${ }^{18}$
17 Tammisaari mainitaan pahamaineisena leirinä myös Käskyssä.

18 Saksan vaikutus on Suomen hauskin mies -elokuvan keskeisin historiallinen teema. 
Raja 1918 kuvaa valkoisen Suomen autoritäärisenä ja epäinhimillisenä valtiona. Bolsevikkien terroria pakenevien ihmisten aalto saapuu Venäjältä Suomen rajalle. Munck pyytää Helsingistä ohjeita. Vastaus tulee nopeasti: raja on pidettävä suljettuna, vain suomalaiset ja muiden valtioiden kuin Venäjän kansalaiset saa päästää maahan. Raja-asemalle rakennetaan piikkilangalla rajattu karanteenialue. Kun se alkaa olla toivottoman täynnä, Munck huudahtaa turhautuneena: "Ampuako ne kaikki pitää?" "Lahtarin" perustyyppiä vastaava Munckin alainen, luutnantti, esittää "inhimillisemmän" ratkaisun: ammutaan vain venäläiset ja punaiset, kuten ohjeistus kuuluu. Väki- ja mielivalta ovat ottaneet Suomessa vallan elokuvan historiatulkinnassa. ${ }^{19}$

Täällä Pohjantähden alla II kuvaa, miten radikaali oikeistolaisuus ottaa vallan muun muassa lasten koulutuksesta. Kylän koulun opettajana toimiva suojeluskuntapäällikkö marssittaa lapsia iskusäkeitä hokien, johon kaikki lapset eivät kuitenkaan alistu. Vankeudesta hengissä selvinnyt, mutta tarkkailun alaisena oleva Akseli sen sijaan vain määrää lapsensa opettelemaan koulukirjan valkoisen tulkinnan sisällissodasta, koska haluaa tämän pärjäävän yhteiskunnassa. Samainen opettaja toteaa kylän aikanaan punaisten puolella olleille miehille, että "se, mikä vuonna 1918 jätettiin puolitiehen, viedään nyt loppuun". Kun miehet vertaavat virallisen Suomen nykyhenkeä Mussolinin Italiaan, opettaja vain innostuu ja kehuu Italian ja Saksan "kansojen" tahtoa poistaa sosialismi yhteiskunnistaan.

Jääkäriupseeri Salpakarille ideologia on ollut puolestaan yksinkertainen valintakysymys, kuten hän järkyttyneille vanhemmilleen toteaa: hän, "papin poika ja pakana", valitsi kommunismin ja fasismin välillä ja päätyi fasismiin. Elokuva rinnastaa punaisten vallankumouksen ja Mäntsälän kapinan, eikä se jätä katsojaa epätietoiseksi siitä, että johtajia lukuun ottamatta oikeistolaiseen kapinaan osallistuneet armahdettiin, täytenä vastakohtana sisällissotaa seuranneine massiivisine punaisten teloituksineen. Myös vuoden 1968 filmatisoinnissa Salpakarin fasismi on ilmeistä, samoin hänen vallankumouksellisuutensa.

Pohjantähden ääri-ideologioiden rinnastamista lukuun ottamatta epäilemättä merkittävin lähes täysin vaiettu aihe sisällissodan muistelussa ja pääosin myös historiantutkimuksessa on punaisten johdon toiminta sodan lopussa ja sen jälkeen. Sama koskee elokuvaa, joskin on yksi merkittävä poikkeus, Täällä Pohjantähden alla II. Elokuvassa entinen punakaartin paikallinen esikuntapäällikkö, kapinaan kiihkeimmin ihmisiä yllyttänyt Hellberg on tullut salaa Venäjältä Suomeen ja ottaa yhteyttä Akseliin tarkoituksenaan tämän värvääminen kommunistien maanalaiseen toimintaan Suomessa. Akseli toteaa, että ajatus on mahdoton, sillä häntä paitsi seurataan erittäin tarkkaan, niin hänellä on myös pienet lapset ja torpan velat vastuullaan. Hellberg syyttää Akselia epäsuoraan pelkuruudesta ja kysyy, onko tämä tosiaan "heittänyt kirveen kokonaan järveen". Akseli - täysin perustellusti - räjähtää: "Häpee, saatana, puheitas! Muistatkos sellaista aikaa kun sen kirveen olis pitänyt pysyä kädessä? Kukas silloin heitti kirveen menemään, minäkö? Minä en ole edes pyssynsuun edessä kuunnellut tuollaisia puheita, saatikka nyt, pidä se mielessäs!"

Hellberg tajuaa menneensä liian pitkälle ja yrittää tyynnytellä Akselia. Tämä kuitenkin jatkaa:"Kun minä viimeisenä päivänä kysyin neuvoa esikunnasta, muuta ei kuulunut kuin juopuneitten mölinää... jumalauta!" Hellberg pyytää anteeksi ja toteaa, että tarkoitus ei ollut loukata. Hän tajuaa selvästikin vasta nyt, että Akseli kokee, että hän ja muu punaisten ylempi johto on pettänyt tämän ja muut kaartilaiset, ja siksi yritys vedota Akselin aatteellisuuteen tämän
19 Ks. myös Varpio 2009, 462 Salmisen $(2007,218)$ mukaan muun muassa ruotsalaisissa tiedotusvälineissä Suomen sisällissodan raaka sodankäynti ja sen jälkeiset massiiviset teloitukset yhdistettiin "suomalaisen rodun" piirteisiin. Ks. myös Hentilä 2018, 41-43. 


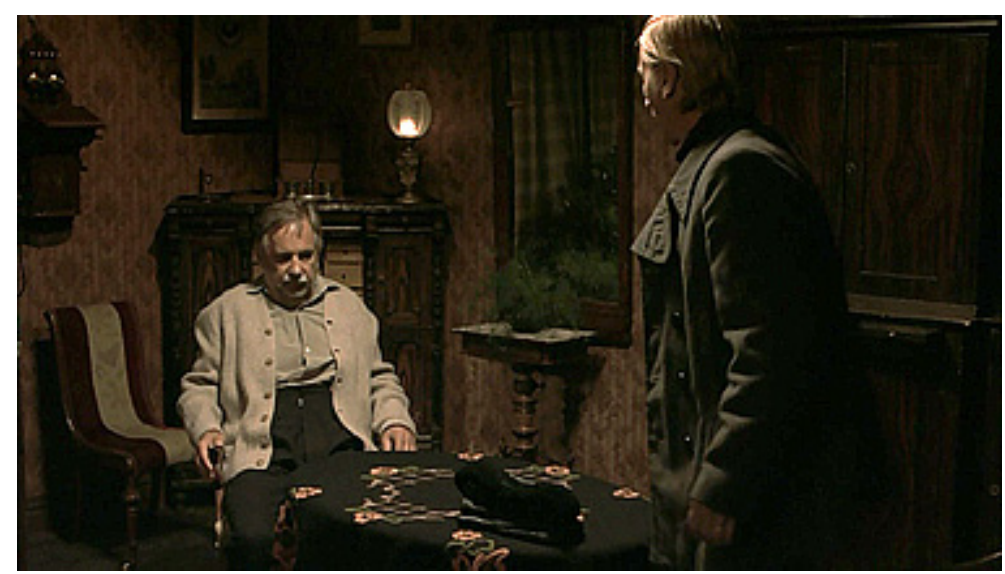

Akseli Koskela antaa Venäjälle paenneen punajohtaja Hellbergin kuulla kunniansa. Kuvakaappaus DVD:Itä.

aktivoimiseksi uudelleen vallankumoukselliseen toimintaan on epäonnistunut täydellisesti. Akseli toteaakin ennen lähtöään:"Yhden asian minä sanon: sinä jätit minulle esikunnan pöydälle kirjeen kun lähdit livohkaan. Se viimeinen lause oli, että 'toimi oman harkintasi mukaan'. Silloin minä päätin, että niin minä tulen aina tekemään, ja niin olen tehnyt!"

Mikäli sisällissotamuistelun keskiössä ovat pitkään olleet punaiset uhrit, on punaisten johto, Suomen kansanvaltuuskunta, käytännössä kirjoitettu sisällissotamuisteluiden ja -historioiden marginaaliin tai kokonaan ulkopuolelle. Tämä näkyy myös yllä analysoiduissa elokuvien katsojille antamissa historiallisissa tiedoissa: valkoisilla on hallitus ja Mannerheim ylipäällikkönä. Punaisilla ei ole kumpaakaan, ei johtoa eikä ylipäällikköä. Todellisuudessa punaisten ylipäällikkyys oli pääosin siviilitaustaisten henkilöiden hallussa (Hoppu 2009, 117-118), mikä pieneltä osin selittää, miksei asiaa mainita edes Olssonin Näsilinna-elokuvan alkuteksteissä, jotka muuten antavat katsojalle muita elokuvia enemmän tietoa sisällissodan kokonaiskuvasta. Punaisen Suomen hallitus oli puolestaan Suomen kansanvaltuuskunta, mutta miksi punaisten ylimmästä johdosta ei sanota mitään? Asiaan ei ole suoraa selitystä, sillä vaikenemisesta ei ole olemassa todistusaineistoa.

Aiheen käsittelyn harvinaisuuden takia käyn läpi kansanvaltuuskunnan vaiheet, sillä se on merkittävä kysymys myös sisällissotaelokuvan tapauksessa: voi kysyä, miksi lähes valmiilta elokuvakäsikirjoitukselta tuntuva tarina ei ole kiinnostanut tuottajia. Punaisten aloittaman kapinan virallinen nimi oli "työväen vallankumous", jonka Suomen kansanvaltuuskunta julisti alkaneeksi 28.1.1918. Sisällissotaan johtaneen vallankumouksen epäonnistuttua termi poistui arkikäytöstä, joskin hengissä säilyneet punaisten johtajat ja kommunistihistorioitsijat käyttivät termiä myöhemmin. (Haapala 2009, 12.) Kansanvaltuuskunnasta "punaisen Suomen hallituksena" ensimmäisen kokonaisesityksen laatinut Osmo Rinta-Tassi (1986, 17-18) toteaa, että kyseessä on siviilihallintoa koskeva tutkimus. Perusteltu määritelmä hätkähdyttää, sillä kyse oli kuitenkin aseellisesta vallankumouksesta (työväenliikkeen johto käytti myös rinnakkaista termiä "vallanotto"). Kuten yllä totesin, elokuvissa sota yleensä vain "alkaa" - sama koskee populaari- ja historiaesityksiä. Haapala (1995, 223-225, 240-242, 261-262) kuitenkin painottaa politiikkaa, siis poliitikkoja, vallankumouksen ja sisällissodan aiheuttajana: sisällissota ei "alkanut" vaan se aloitettiin.

Vallankumoushallituksen ote alkoi herpaantua maaliskuun 1918 jälkipuoliskolla. Rinta-Tassin (1986, 479-482) mukaan kansanvaltuuskunta oli eräänlai- 
sen "ideologisen uhon" vallassa, jossa todellisuus jäi syrjään: luokkataistelua oli jatkettava niin kauan kuin se vain oli mahdollista. Eräs huomiota herättävimmistä piirteistä kansanvaltuuskunnassa on, että sotaonnen käännyttyä kansanvaltuuskunta perusti Suomeen "diktatuurihallituksen" (siis määritti itsensä diktatuurihallitukseksi), jonka pelkällä nimellään luulisi päätyneen lukuisiin suomalaisiin sisällissodan historiaesityksiin. Näin ei kuitenkaan ole syystä tai toisesta käynyt, päinvastoin. Termiin törmää Rinta-Tassin historiateoksen (ks. 465-471) ja joidenkin tutkimuksien ohella lähinnä aikalaislähteissä, kuten sanomalehdissä, joissa nimitystä käytettiin käytännössä annettuna - siis sellaisena kuin se punaisen hallinnon tiedonannoissa esiintyi. Diktaattoriksi valittiin kokemäkeläinen pappissukujen poika Kullervo Manner (1880-1939), joka oli sittemmin SKP:n ja Kominternin perustajajäsen ja joka kuoli epäsuosioon jouduttuaan työleirillä Neuvostoliitossa tammikuussa 1939.

Kansanvaltuuskunta alkoi toteuttaa ihmisten ja materiaalin evakuointia sotaonnen käännyttyä ratkaisevasti. Tähän kuului kaikki mukaan saatava varallisuus, muun muassa Suomen pankin rahavarannot. Lopulta saarrostusuhan alla kansanvaltuuskunta päätti paeta Venäjälle ja sai punakaartilaiset uskomaan, että heidän pakonsa oli välttämätön, punakaartin "rivimiehet" kyllä armahdettaisiin. Kun paon ilmeinen ristiriitaisuus nousi ihmisten tietoisuuteen, kansanvaltuuskunta asetti keskuudestaan komitean tutkimaan asiaa. Sen lopputulema oli yksiselitteinen: pako oli välttämätön, sillä ei ollut mitään syytä jättää johtajia "lahtarien revittäväksi". (Rinta-Tassi 1986, 485496.) Heidän kapinaan nostattamilleen ihmisille kävi pääsääntöisesti paljon huonommin, kuten muun muassa 2000-luvun sisällissotaelokuvat korostavat - mutta johtajien ratkaisusta ne vaikenevat täysin.

Pohjantähden Akseli on siis harvinainen sisällissotafiktion hahmo, joka antaa punaisten johdon kuulla kunniansa kapinaan nostattamiensa tavallisten ihmisten pettämisestä tappion varmistuttua. Jo vuoden 1968 filmatisoinnissa Akseli kertoo Hellbergin paenneen ja jättäneen pakolaiset hänen kontolleen. Kansanvaltuuskunnan unohtamista - tiedostamatonta tai tiedostettua - on pidettävä Suomen sisällissodan historian käsittelyn merkittävimpänä aukkona. ${ }^{20}$ Tämä koskee myös kotimaista elokuvaa, joka reflektoi sisällissodan muistelun ja historiankirjoituksen painotuksia.

\section{Lopuksi}

Täällä Pohjantähden alla II:ssa punaiset saavat hautamuistomerkin välirauhan aikana. Sen siunaamistilaisuudessa kirkkoherra kutsuu vainajia "veljikseen ja siskoikseen", jotka Herra kutsuu nyt luokseen. Hänen poikansa, joka johti teloituksia Pentinkulmalla, osallistuu tilaisuuteen välinpitämättömän näköisenä. Janne Kivivuori pitää työväenyhdistyksen seppelepuheen. Hän toteaa, että kärsimykset - siis punaisten - voidaan vihdoin unohtaa, mutta vain sillä ehdolla, että "20 vuotta jatkunut tanssi näillä haudoilla lopetetaan". Ainakin julkinen "tanssi" on epäilemättä päättynyt jo ajat sitten, mutta kärsimyksiä ei olla unohdettu - päinvastoin, ne hallitsevat sisällissodan representaatioita ja sen käyttöä allegoriana tämän päivän poliittisissa vastakkainasetteluissa, kuten viime aikoina muun muassa Suomen nykyhallituksen työttömien aktiivimallin kritiikissä sekä turvapaikanhakijakriisin synnyttämissä reaktioissa. Tendenssille ei tätä kirjoitettaessa näy loppua, pikemminkin sisällissodan käyttö historiallisena viittauskohteena on lisääntynyt viime aikoina, mikä on osin selitettävissä Suomen 100-vuotisjuhlan ja sisällissodan 100-vuotismuiston kautta.
20 Turun vuodesta $1917-1918$ tutkimuksen tehnyt Rauno Lahtinen $(2016,9-10,371-407)$ epäilee, että ennen hänen kirjansa julkaisua (2016) harva sisällissotaa kokematon turkulainen on kuullut Turun vuoden 1918 tapahtumista juuri mitään. Paikallisia punaisten johtajia ei mainita edes paikallisen työväenliikkeen myöhemmissä historiikeissa. 
2000-luvun teatterilevitykseen tuotetuissa elokuvissa painottuvat sisällissodan verisyys sekä sodan loppupuoleen ja jälkiseurauksiin keskittyminen, jossa keskiössä ovat punaisten kärsimykset. Valkoiset määrittyvät ensi sijassa (mies)sotilaiksi, kun taas punaisia edustavat ennen kaikkea naiset. Elokuvissa on läsnä ajatus, jonka mukaan valkoiset voittivat itse sisällissodan, mutta pidemmällä aikavälillä ainakin moraaliseksi voittajaksi nousivat punaiset. Elokuvat pyrkivät vakuuttamaan katsojat historiakuvansa autenttisuudesta. Tarkempi analyysi paljastaa, että samalla ne välttävät ottamasta kantaa siihen, miksi sota syttyi ja kuka sen aloitti - tyypillisesti sisällissota vain "alkoi".

Elokuvat korostavat valkoisen Suomen nationalismia ja fasistisuutta. Suurin aukko elokuvien sisällissotakuvauksessa on puolestaan punaisten johdon, diktatuuriksi julistautuneen Suomen kansanvaltuuskunnan täydellinen sivuuttaminen - siitä huolimatta, että sen tarina sisältää kaikki toimivan elokuvakäsikirjoituksen elementit. Mikä merkittävintä, tämä korreloi sisällissodan muisteluiden ja esittämisen kanssa ylipäätään: pääpaino on rivipunaisten kohtaloissa, valtaosa sisällissotanarratiiveista ei mainitse Venäjälle paennutta kansanvaltuuskuntaa lainkaan. Voi ajatella, että hävinnyt osapuoli puolestaan hylkäsi entisen hallituksensa sisällissodan muistelun ulkopuolelle, ja tätä reflektoi myös 2000-luvun sisällissotaelokuva.

\section{Lähteet}

\section{Elokuvat}

Käsky (2008), ohjaus Aku Louhimies, Helsinki-filmi. Suomi, 110 min.

Raja 1918 (2007), ohjaus Lauri Törhönen, Border Productions Oy / Juonifilmi Oy. Suomi, 114 min. Taistelu Näsilinnasta 1918 (2012), ohjaus Claes Olsson, Kinoproduction. Suomi, 75 min. Täällä Pohjantähden alla (2009), ohjaus Timo Koivusalo, Artista-Filmi. Suomi, $181 \mathrm{~min}$. Täällä Pohjantähden alla II (2010), ohjaus Timo Koivusalo, Artista-Filmi. Suomi, 138 min.

\section{Muut lähteet ja kirjallisuus}

Conley, Tom (2011) "The Fall of the Roman Empire: On Space and Allegory". Teoksessa Robert Burgoyne (toim.) The Epic Film in World Culture. New York and London: Routledge, 144-160.

Eerola, Kaisa (2009) Vuoden 1918 dramaturgiat: sisällisotavuoden tulkinta kotimaisen elokuvan kautta 1956-2008. Suomen historian pro gradu -tutkielma. Tampere: Tampereen yliopisto.

Grindon, Leger (1994) Shadows of the Past: Studies in the Historical Film. Philadelphia: Temple University Press.

Haapala, Pertti (1995) Kun yhteiskunta hajosi: Suomi 1914-1920. Helsinki: Painatuskeskus.

Haapala, Pertti (2009) "Sota ja sen nimet". Teoksessa Pertti Haapala ja Tuomas Hoppu (toim.) Sisällissodan pikkujättiläinen. Helsinki: WSOY, 10-17.

Hoppu, Tuomas (2009) "Taistelevat osapuolet ja johtajat". Teoksessa Pertti Haapala ja Tuomas Hoppu (toim.) Sisällissodan pikkujättiläinen. Helsinki: WSOY, 112-144.

Kujanpää, Heikki (2018) "Ohjaajan sana". Teoksessa Suomen hauskin mies: mediainfo. Nordisk Film.

"Kulissien takana - making of" (2008). Teoksessa Käsky DVD. Helsinki: FS Film.

Lahtinen, Rauno (2016) Punainen Turku 1917-1918. Turku: Sammakko.

Liukkonen, Marjo (2018) Hennalan naismurhat 1918. Helsinki: Vastapaino.

Mähkä, Rami (2016) Something Completely Historical: Monty Python, History and Comedy. Turku. 
Mähkä, Rami (2017) "Monty Pythonin komedia vastaelokuvana". Lähikuva 1/2017, 7-25.

"Näin tehtiin Raja 1918" (2007). Teoksessa Raja 1918 DVD. Helsinki: FS Film.

Peltonen, Ulla-Maija (2003) "Vuoden 1918 muistot". Teoksessa Anja Kervanto Nevanlinna ja Laura Kolbe (toim.) Suomen kulttuurihistoria 3: oma maa ja maailma. Helsinki: Tammi, 192-198.

Piiroinen-Honkanen, Marja (2006) Punakaartin aseelliset naiskomppaniat Suomen sisällissodassa 1918. Sipoo: Omakirja.

Rinta-Tassi, Osmo (1986) Kansanvaltuuskunta punaisen Suomen hallituksena. Helsinki: Valtion painatuskeskus.

Roselius, Aapo (2006) Amatöörien sota: rintamataisteluiden henkilötappiot Suomen sisällissodassa 1918. Helsinki: Valtioneuvoston kanslia.

Rosenstone, Robert (2000) "Oliver Stone as Historian". Teoksessa Robert Brent Toplin (toim.) Oliver Stone's USA: Film, History, and Controversy. Lawrence, KS: University Press of Kansas, 26-39.

Rosenstone, Robert (2013) "The History Film as a Mode of Historical Thought". Teoksessa Robert Rosenstone ja Constantin Parvulescu (toim.) A Companion to Historical Film. Malden, MA: Wiley-Blackwell, 71-87.

Salmi, Hannu (1993) Elokuva ja historia. Helsinki: Suomen elokuva-arkisto.

Salmi, Hannu (1996) "Spektaakkeli monumenttina: Historiallisuuden merkkejä 50- ja 60-luvun antiikkispektaakkeleissa". Lähikuva 5/1996, 10-15.

Salmi, Hannu (2001) "Menneisyyskokemuksesta hyödykkeisiin: historiakulttuurin muodot". Teoksessa Jorma Kalela ja Ilari Lindroos (toim.) Jokapäiväinen historia. Helsinki: Suomalaisen kirjallisuuden seura, 134-149.

Salminen, Esko (2007) Päättymätön sota 1918: Sisällissota julkisessa sanassa 1917-2007. Helsinki: Edita.

Schivelbusch, Wolfgang (2004) The Culture of Defeat: On National Trauma, Mourning and Recovery. Kääntänyt Jefferson Chase. New York: Picador.

Tikka, Marko (2004) Kenttäoikeudet: välittömät rankaisutoimet Suomen sisällissodassa 1918. Helsinki: SKS.

Varpio, Yrjö (2009) "Vuosi 1918 kaunokirjallisuudessa". Teoksessa Pertti Haapala ja Tuomas Hoppu (toim.) Sisällissodan pikkujättiläinen. Helsinki: WSOY, 441-463. 